\title{
ethic@ \\ ETHICS AFTER INTERVENTION: SHOULD WARLORDS BE EMPOWERED AS STATESMEN?
}

\author{
DANIEL DUARTE FLORA CARVALHO ${ }^{1}$ \\ (UFPel, Brazil)
}

\begin{abstract}
Since the end of the Cold War, when the number of peacekeeping and peacebuilding interventions considerably increased, the debate about their ethics raised as an important aspect regarding both its ends and its means. Literature was roughly divided between those who advocated for an approach centred on global actors, liberal peace, and cosmopolitanism and those who stood for the role of local actors and indigenous solutions for the problems in question. In this regard, the relationship that the International Community usually held with warring parties in civil conflict came to the fore. This essay looks forward to providing insights about the role that warlords can play in facilitating and hindering internationally-led peace process. Using Burundi and Somalia as case-studies, it is argued that warlords can only commit to liberal and cosmopolitan ethics after the state institutions have been built and solidified.
\end{abstract}

Key words: Civil War. Intervention. State-building. Post-conflict reconstruction.

Much have been said about the ethics of intervention, mainly of armed intervention, in intrastate conflicts around the world. Specially after the end of the Cold War, when such type of warfare became much more recurrent, the International Community (mainly through the United Nations) intervened several times in domestic conflicts in order to cease the violence and to assist the war-torn states' reconstruction. Since then, the debate was mostly limited and restrained to the question of whether thirdparty armed intervention was a good approach in pursuing such goal. On one hand, the moral necessity of intervening and protecting "populations from genocide, war crimes, ethnic cleansing and crimes against humanity", which came to be famous under the label Responsibility to Protect. On the other hand, a "do no harm" approach which advocates that third-party international armed intervention cannot cause more damages to a state under intervention, which became known as Responsibility while Protecting. Many authors and policymakers engaged in such debate (Evans, 2008; McDougall, 2014).

However, similarly important and sensitive questions apparently remained largely unaddressed and, consequently, unanswered and are related mainly to the actors which will engage in both peace-making and state-building processes. This is a critical issue provided that the responsibility of reconstructing state institutions and their future maintenance will lie on domestic actors, no matter how profound an intervention can be 
(Ramsbotham, Woodhouse, \& Miall, 2011; Mills, 2014). This fact is due to a simple reason: interventions are neither made nor intended to last forever and this is one of the reasons that several ethics issues are raised about them regarding - among others - the type of intervention that is supposed to be deployed and, consequently, what type of state is supposed to be built (Lidén, 2009). In many cases where crises arouse and the International Community intervened, it backed power-sharing agreements and transitional governments came forth with several domestic actors participating in it.

This praxis was the case after electoral crises in Kenya (2007) and Zimbabwe (2008), where international mediation - not intervention - established power-sharing agreements conducing Kenyan Raila Odinga and Zimbabwean Morgan Tsvangirai to be prime-ministers of their respective countries and sworn in Kenyan Mway Kibaki and Zimbabwean Robert Mugabe as presidents of their countries. The same praxis was carried out by international intervenors and mediators to put an end to armed conflict between warlords and to (re)building new states institutions in Somalia (2000) and Burundi (2005) (Anonymous, 2002; Cunninghan, 2011). In both cases, actors who engaged in war (warlords) were invited to the table of negotiations in order to draft a new constitution for their countries and thus to become (unarmed) political parties.

For both pair of cases, sensitive questions were raised about the legitimacy of such arrangements. Who chose the actors entitled to participate in them? Were those who chose the actors in a position to do so? Which criteria - if any - did they follow to choose such actors? These questions are the centre of what I call "ethics after intervention" because by and large these arrangements begin to be planned and orchestrated during the conflict de-escalation and when international intervenors are already planning to transfer the control of a state to its citizens, its rightful bearers. This is referred to as "after intervention" because these practises seem to have been taken during the transition from intervention to stabilisation in IRW operations ${ }^{2}$.

The present essay looks forward to narrowing these assessments and questions the following interrogation: should warlords be made into peacebuilders, that is, should the International Community empower and entitle them in order to rebuild their states? This question is important and sensitive because warlords inevitably caused suffering to peoples and acted in complete discordance with cosmopolitan peace and governance. By and large, they have proved to be unreliable and untrustworthy to the constituencies they act upon. On the other hand, they may be the only domestic actors capable of securing 
and sponsoring such process if they are really committed to and, consequently, it is highly likely that they will run the country after intervenors withdrawal. A proper assessment on this issue can help to forecast a number of scenarios in the "uncertain transition from stability to peace", which can range from the likelihood of violence resumption to the transition for a cosmopolitan democracy as a recent CSIS report shows ${ }^{3}$. In this regard, the feasibility of the options in hand and the possible outcomes regarding such arrangements will also be drawn in this essay.

This essay will focus on Sub-Saharan African countries which had undergone a UN-led IRW peace support operation and whose intervention was deployed only after 1992 and concluded as late as 2010. This period begins in the early stages of peacebuilding missions after the publishing of the report An Agenda for Peace and is closed out after a short 3-year interregnum when no UN mission was deployed all over the world. In the period analysed, the number of UN-led operations deployed in SubSaharan Africa was 4 times bigger than in the previous 44 years (United Nations, 2014).

Eight Sub-Saharan African countries fit the time specification mentioned above. Burundi and Somalia were selected for deeper analysis ${ }^{4}$. They all underwent civil war and were intervened by UN missions during the period, show striking similarities like the political goals of warring parties and the fact that they went through interventions which reached different outcomes, having Burundi's mission flirted with success - despite of the recent developments - whilst Somalia's largely failed its objectives (Miller, 2013).

Although ideas and practises of peacebuilding are not new to Africa, dating back to precolonial times, it was only in the aftermath of the Cold War that such practise came to the fore after the publishing of the UN Secretary General's report An Agenda for Peace, in 1992 which is considered a milestone in what concerns UN IRW operations (Curtis, 2013). Such report was important because it provided definitions for the different types of interventions the UN could deploy. Specifically, it claimed that peacebuilding operations were aimed to identify and support "structures which will tend to strengthen and solidify peace in order to avoid a relapse into conflict" (United Nations, 1992).

Even if such report came down in History for systemising methods for prevention and solving conflicts, it was the first UN official document which drew attention to the fact that threats to peace were more likely to come from inside the states. For this reason, missions had to address different challenges and evolve specific policies and techniques that ranged from organising and administering elections to assisting the creation of free- 
market oriented economy. Still, scholars continued claiming that there is "no reliable formula for transforming a fragile ceasefire into a stable and lasting peace" for different countries may have entered into a spiral of violence for different reasons, demanding thusly different solutions (Paris \& Sisk, 2009). In this regard, there were structural changes in peace operations during the 1990s and the 2000s. More and more, new actors like NGOs and international and regional organisations became involved and demonstrated commitment to what can be called "liberal peacebuilding" or "liberal peace" (Duffield, 2001; Curtis, 2013).

The greatest change in peace operations, however, seems to have been not the proliferation of actors and institutions tasked with peacebuilding, but with the expansion of the peacebuilding activities. Until the latest years of the 1990s, peace operations used to devote more attention and efforts in order to build the conditions for basic stability. Until the publishing of the report A More Secure World in 2004, focus was placed solely on cessation of hostilities and in promoting negotiations between the warring parties and on the reconstruction of infrastructure. After that, they began to engage more actively on the promotion and protection of human rights and democratisation.

During the years, the evolution in peace operations concepts and activities led to a debate regarding the conflicts' root causes that the missions were expected to address and how to address them. In this regard, missions began to be organised according to their goals which were determined by the hegemonic current of thought, largely defined by the great powers interests (Doyle, 1999; Duffield, 2001). This not only shaped the way missions were to be organised but also the hierarchy between their aims. As concepts and practises evolved, liberalisation, stabilisation and social justice came to the fore as missions' main goals for peace and state-building (Curtis, 2013). Nonetheless, the tasks of reconstructing state institutions and authority have remained at the core of policies even in the completely absence of consensus amongst both scholars and practitioners about the kind of relations missions should keep with local and international actors and agents and consequently how it would be related to the sequencing of policies. Although there is a strong current of thought which fiercely defends the so-called liberal peace, a new trend seems to be on the rise since the beginning of the 2000 s.

By confronting the successful liberal peacebuilding processes of Namibia and Mozambique against the appalling failures in Angola, Rwanda, Sierra Leone, Sudan and Côte d'Ivoire, the importance of sequencing the policies and, consequently, favouring the 
construction of strong state institutions and authority to the detriment of immediate democratisation and liberalisation gained more attention on policymakers and scholars. It was argued, for example, that reducing states' scope during the 1980s had negatively affected their strength and capacity to rule which produced a new demand for institutions in countries mainly from the Third World and required the reconstruction of institutions and, consequently, states. It was also noted that the first political institution ever created was precisely the state - whose function is to guarantee security and law enforcement followed by the rule of law and political liberalisation (Fukuyama, 2005; 2011).

Following this line of thought, other authors wrote in favour of “institutionalisation before liberalisation". In this regard, it was necessary to build state capacity to promote domestic order before than promoting liberal values and state institutions should be empowered with coercive power and rational-legal authority in order to deal with the issues arising from political and economic liberalisation. Besides, attention was also called to the fact that "where chronic, extreme exclusion persists, inclusionary efforts may in fact trigger armed uprisings through raised expectations" (Paris, 2004; Call, 2012, p. 158). Soon, this preoccupation began to be incorporated in UN reports and actions on the ground. As early as 2004, for instance, the UN High-Level Panel on Threats, Challenges and Change made out a case for improved policy on states' institution-building and, six years later, a change on the name of a UN peace operation exposed this new focus of concern: the United Nations Organisation Mission in the Democratic Republic of Congo (MONUC) became the United Nations Organisation Stabilisation Mission in the Democratic Republic of Congo (MONUSCO). Adding the word "stabilisation" was the façade of the new goals to be pursued. MONUSCO was now responsible for "assist the Congolese government in strengthening military capacity, and to support the Congolese government in consolidating state authority" (Curtis, 2013, p. 12).

In fact, the emphasis given on stabilisation, state authority and state-building proved to be somewhat efficient in bridging warring parties and thus was capable of reducing the number of civil wars not only in Sub-Saharan Africa but in the whole world but, on the other hand, foundered on promoting development and improving living conditions for the war-affected populations. According to the A More Secure World report (2004, p. 33), this success in "negative peace" was only possible "because the United 
Nations provided leadership, opportunities for negotiation, strategic coordination, and the resources needed for implementation".

Promoting and coordinating negotiation between warring parties, however, may have been one of the reasons that led many UN peace operations to be successful in ending conflicts and promoting stability but fell short for a more inclusive and democratic peace. In late 2005, the Security Council passed a resolution which stablished the Peace Building Commission, an intergovernmental advisory organ which had as main purposes "to bring all relevant actors to marshal resources and to advise on and propose integrated strategies for post-conflict peacebuilding and recovery" and "to focus attention on the reconstruction and institution-building efforts necessary for recovery from conflict and to support the development of integrated strategies in order to lay the foundation for sustainable development" (United Nations, 2005).

This approach was formalised in this resolution a couple of years after the signature of the Lomé Accord, which brought the Sierra Leonean civil war to an end. Basically, the peace agreement did not include legal instruments for development and economic liberalisation. It was largely an accord in which parties would celebrate their commitments to put an end to hostilities, to create conditions that would make DDR ${ }^{5}$ possible and to allow the Revolutionary United Front (RUF) to become a political (unarmed) party. As it was put, the Lomé accord was focused on balancing interests of the politically powerful actors as most of the peace agreements had been done thus far (Molloy, 2004) ${ }^{6}$.

Taking this case and the provisions it used, an important question comes forth: what are the criteria used to consider an actor as relevant or politically powerful? Liberal peacebuilding claims that actors should be assessed as regards their behaviour and accordance to liberal peace. In this regard, spoilers - those who "violently disagree with liberal peace" - should be socialised or marginalised (Curtis, 2013, p. 11). Also, ethical standards for evaluating peacebuilding are expected to meet the mission's autonomy, which should promote a balance between global and local politics, and its commitment to meet fundamental human needs (Lidén, 2009, p. 619).

What is obviously clear is the strong connexion between the criteria presented to assess both warring parties and peace missions. In this regard, it can be said that the latter is a useful tool for assessing the former. The warlords (or warring parties) are the ones expected to act in accordance to stabilisation at the first moment and to the liberal peace 
at a later moment (even if political liberalisation is to take place before economic liberalisation) because they will be the new political actors of a pacified country, that is, they will run its institutions and govern the state. Therefore, there should be an in-depth discussion about what qualifies a warlord to build the new state's institutions and then become a statesman. Empowering warlords as statesmen is an action whose consequences must be clear and policymakers should be fully aware of them. First, it is necessary to have in mind that the term "warlord" carries a pejorative meaning that is not accurate and overshadows the political motivations and reasoning of the actor named after it; and second, how constituencies will interpret it and whether they will accept having warlords as their new rulers is a matter of debate.

Warlords have frequently proved to master political calculations not only when they conclude it is time to engage in violence but, also and most importantly, when it is time to disengage and negotiate peace. However, recognising them as political actors who should be entitled to negotiate and to rebuild the state and eventually giving them access to a share of the state power may send a message to other actors alike. It may encourage groups in violence-prone states to rage against the state aiming to achieve a political goal, leading to the militarisation of local politics and consequently to the constant escalation of violence. The risk then is that the idea of the state as an object of bargain may be reinforced, instead of suppressed. Also, constituencies that will hypothetically be governed by warlords may understand it as an international disdain towards war-torn societies. For instance, by simply mediating the issue and leaving warlords to settle postconflict status quo, an outcome where democracy and openness to cosmopolitan values is unlikely to happen unless the mediator is skilled enough to lead the parts to commit to it.

It can thus be argued that such actors must be in complete accordance to the goals and values of stabilisation and liberal peace in order to be entitled to become an unarmed political actor and likely to run the country when the intervention is over. The issue raised concerning it, however, is about trust. It can be argued that such actors should not be allowed to participate in the country's reconstruction because they have been responsible for its failure like Charles Taylor's NPFL in the First Liberian Civil War (1989-97) and Ali Mahdi Muhammad and Mohammed Farrah Aidid's USC in the eruption of the Somali civil war in $1991^{7}$ (Duyvesteyn, 2005). 
These two groups and three individuals proved somehow to be unreliable and untrustworthy for the International Community since they caused severe pain and traumas to civilians and challenged any ethical standard it may pursue. Liberia's Charles Taylor is said to have been elected president of the country following the provisions of UNbrokered peace agreements signed between 1993 and 1996 because people were afraid of reprisals if they didn't vote for him. Also, Somalia's Mohammed Farrah Aidid moved his military against international intervention forces when he realised they didn't have public support and were preventing him to accomplish his political and military goals. In cases like these, the only way out of the crisis seems to be a peace-enforcement mission that would impose liberal peace institutions which would be run by global civil society until the target population is ready to be in charge of it accordingly. Some say that this was exactly UN Secretary General Boutros Boutros-Ghali's goal with UNASOM I ${ }^{8}$. This goal however caused not only fury amongst warring parties but also a deep malaise within Somali society since the new political rules and institutions in the country intended by the mission were very different from the previous ones that the country took centuries to build (Woodward, 2003).

Somalia is therefore a country that supports the arguing case in favour of warlords' inclusion and empowerment as peace-builders and statesmen later on but it is somewhat limited in this regard. Following the failures of both UNASOM I and II, several reconciliation summits were held by international mediators in order to rebuild Somali state. The situation that emerged with the ousting of Siad Barre in 1991 dissolved the country into a Hobbesian 'state of nature', where several armed groups competed for filling the power vacuum, especially in the south, which led the United Nations to mediate negotiation between warring parties aiming mainly at promoting cease-fires. The shortlived Dirigil-Mirifle Governing Council established in 1994 was the first case in which it was attempted to empower warlords as statesmen (Menkhaus, 1996; Patman, 2007).

After the UN withdrawal, its neighbouring countries began to play a more active role in the reconstruction of the Somali state and sponsored all the 15 attempts for national reconciliation that took place until 2006 which were made more difficult due to the "legacy of a deep distrust among Somalis toward the state as an institution itself" (Menkhaus, 2006, p. 94). The difficulties now were, as pointed out by Clapham (2013), whom to negotiate with, since the warlords controlled enough forces to make deals successful or ruined; and what to negotiate about, since the state was in a situation of 
complete collapse, there was no rewards for those committed on state-building negotiations.

In the midst of this dynamic, the National Peace Conference of Somalia, held in Arta, Djibouti, in 2000, achieved as a main result the creation of the National Transitional Government (GNT). Nonetheless, the process left out some important clans which were responsible for jeopardising peace and thus was unable to reach national reconciliation (Anonymous, 2002). Despite its flaws, the fact that the process of Arta has originated a government that managed to inaugurate institutional structures for the country allowed it to be recognised by the International Community. Thence, warlords became statesmen and - whilst representing Somalia - began to occupy its seat at the UN and the African Union (AU).

Clashes between clans and factions and the TNG in Somalia made the latter gradually weaken until it ceased to exist in 2002. Although it was the $13^{\text {th }}$ failed attempt to recreate a central authority in Somalia, the country did not fall in total chaos afterwards. Rather, a new attempt immediately began and was concluded in 2004, with the founding of the Transitional Federal Government, which emphasised power-sharing amongst warring parties and did not address serious conflicts issues but succeeded - not only without external help - to manage crisis and to allow the integration of important figures from the Islamic Courts Union in 2008.

The Somali case is an important indicative that state-building processes must find a balance between global and local and to recognise that those who conducted a state to its failure or collapse may be the responsible ones for its reconstruction. Although it is still weak and dependent on foreign forces, Somali Federal Government - the amalgam of warring factions - is slowly succeeding to bring order and predictability on daily life to its people. Although it is true that Mogadishu dwellers, for instance, still live with the constant menace of terrorist attacks perpetrated by the Islamic militia Al Shabab, it is also true that life is slowly coming back to normal with hotels and restaurants returning to function - a clear comeback (Al Jazeera, 2014).

Should this hold the case for other war-torn states, it is necessary to question whether the inclusion of warlords should be inclusive or if some criteria must be met. As the Somali case indicated, warlords deserved a seat on the table of negotiations since they are the ones who will occupy the post-war institutions and run the country and will probably be the only actors with (military) capacity for doing so. Furthermore, excluding 
some groups may have ambiguous consequences. It has the potential for prolonging the conflict since spoilers are not given any chance to peacefully reach its goals. In this case, it is logical that they would continue engaging on war and raging against the state unless they are convinced that the war is unwinnable, which may require a strong military international intervention. In Sierra Leone, for example, the Revolutionary United Force was only convinced of it when British troops started backing the UNAMSIL (Curran \& Woodhouse, 2007).

Somalia presented two different moments in this regard. First, the UN interventions tried to promote negotiation with limited numbers of warring groups in an attempt to build cease-fire and to create a propitious environment for its work. As this strategy blatantly failed, it attempted to promote more inclusive talks amongst warlords which resulted in the Dirigil-Mirifle Governing Council and so did the following reconciliation conferences. This kind of approach, however, seems to have been further discarded by the UN, after the passing of UNSC Resolution 1645 of 2005, which leaves two unanswered questions. First, is there any reason (besides stubbornness) for rejecting the promotion of inclusive talks? Second, what would be the threshold that put aside those who are in a position to participate in the talks and those who are not?

Ethical and power criteria as well as the strategy of the mediator offer some important insights for answering these two questions. First, as it has already been said, it would be helpful if some ethical criteria could be met. The parties should be and should act in accordance to the intervenors' or mediators' principles and goals. This is not an easy thing to prove. Actors who engaged in warfare only did so because they knew they could reach their goals through the use of force, which is clearly opposite to what any mediation or intervention wants to promote in the target country. In this regard, the foreign (diplomatic or military forces) have to find a way to low down the expectations about the benefits of war and persuade them to join the negotiations, what can be done by presenting a stronger military force or by isolating the actor.

Second, actors who are fighting for the state must be willing to share power in post-war institutions and government. Again, this is not a question of benevolence from the warring party, but a matter of rational calculation. If the state is the prize they are fighting for, power-sharing may prove to be the second-best outcome they can get. It is a matter of rational calculation: when they note they will not achieve their goals (seizing 
the entire state institution and running it), they abdicate of a part of it in order to ensure their prize to be as big as possible.

There is actually not much of "ethical" in both situations. It is difficult to request commitments to democracy, human rights, economic and social progress etc. from an actor who has already striven against it. Firstly, liberal democracy and human rights like Western agents defend may be seen by warring leaders and by the population they claim to liberate as alien values. Also, even if warlords commit to democracy in the short run, they are likely to appropriate such discourse to canalise public opinion in the making and unmaking of enemies. Secondly, democracy and political liberalisation may have been the reason for which the tensions escalated and the conflict erupted (Mansfield \& Snyder, 2005; Riedl, 2014). In countries like Republic of Congo, Liberia and Burundi, democratisation conduced fractious political systems to bloody civil wars. Lastly, economic and social progress may sometimes be the price to be paid in exchange for stability and negative peace. By and large, African rulers have sacrificed growth and development-oriented policies in order to sustain client-patron networks that strengthen their hold to power and there is little reason to believe that this situation could be changed by both incumbents and defiants (Englebert, 2000b; Acemoglu \& Robinson, 2010).

It is also very unlikely that they will voluntarily cope with such objectives. Following this scenario, power criteria are apparently the natural threshold for selecting the warlords who will negotiate. First, the warring groups must have internal cohesion. If they don't, any accord reached will come to the fore in an extreme fragile situation because one of the parties lacks power over its constituents and cannot therefore guarantee they will cope with the accords provisions, which would only perpetuate the conflict. Second, and directly related to the group's internal cohesion, is the issue of veto players, that is, actors "whose consent is required for policy to change". This is an important issue because not only it is closely connected to the duration of the war, but because civil wars usually contain "set of actors that have separate preferences over the outcome of the conflict and separate abilities to block and end the war". In this regard, it is an actor which cannot be excluded from the peace talks and that must have internal cohesiveness (Cunninghan, 2011, p. 32 and 15).

Burundi is a case in which intervenors and mediators attempted to follow such criteria in order to bring actors to the table of negotiations and to consequently rebuild the state. Since its independence in 1962, Burundi was never a stable country. Throughout 
its history, several coup d'états and civil wars which resulted in mass killings of Hutus twice - that some called genocide - were recorded. The period between 1993 and 2005 was perhaps the bloodiest in that tiny country's history. The civil war that broke out after the country's first democratic elections were held inserted Burundi into a dramatic spiral of violence and underdevelopment that was only halted due to international mediation and which led the country to hold in 2010 new democratic (and problematic) elections. Even so, the country was still seen as a case of likely success in state and peacebuilding.

Although the peace process had "ostensibly run its course in war-torn Burundi", policymakers should have been aware that "the road ahead is fraught with peril" (Sisk, 2009, p. 134). Optimism was indeed precipitate and ill-advised. Not only state authority levels began to decay soon after 2008, when the preparations for the 2010 elections started (Worldwide Governance Indicators, 2014), but also events that took place from 2014 on seemed to confirm that a new chapter of violence in the country was to ignite. In fact, the conflagration of a new crisis was everything but unpredictable. As early as 2011, scholars were already reflecting on whether "the suggested solutions based on political forms, procedures and technicalities [were] wrong" and if the "real fundamentals of Burundian politics [were] understood in the political mapping of Burundian future" (African Arguments, 2011).

The election of the president Melchior Ndadaye in 1993 led to a general unrest which resulted in the outbreak of the civil war. Three years later, president Sylvestre Ntibantunganya was persuaded by its East African counterparts (Julius Nyerere and Benjamin Mkapa, Tanzania; and Yoweri Musevini, Uganda) to accept a regional peacekeeping force in the country. The intervention was not accepted by Burundian army which promptly ousted him from power. For that reason, Nyerere managed to impose sanctions against the new government which inflamed allegations that he was being partial (Southall, 2006).

Julius Nyerere had, however, a strategy of isolating some actors to decrease their incentives for continuing raging the war. Fully aware that the facilitation team had a major role in setting the agenda and determining who would be at the table, he decided not to exclude from the Arusha Process the two main combatants of the war, the Conseil National pour la Défense de la Démocratie - Forces pour la Défense de la Démocratie (CNDD-FDD) and the Parti pour la Libération du Peuple Hutu (Palipehutu). Nyerere's strategy was to force both actors to become "late-comers" in the process. By doing so, 
CNDD-FDD and Palipehutu would have to refrain from military actions and to change behaviour in order to join the peace process and achieve some of its goals through peaceful means. The problem, however, is the risk in such action. By forcing military and politically powerful actors to become a late-comer, one likely outcome is that the prizes at stake when they finally join are so small that they would prefer to re-engage in war, which could bring better payoffs. In fact, the immediate consequence of such decision was a striking obstacle to the peace talks since both excluded parties were important veto players. It can be said thus that Nyerere failed to address the power criteria in this case and, consequently, failed also to bring the two main combatants to act in accordance to the ethical criteria.

The road to the second peace process began as early as August 1996 and lasted two years. It was facilitated by president Pierre Buyoya initiative to open unilateral talks with rebels, which included the CNDD but excluded the Palipehutu. In order to persuade rebels to join the peace talks, Buyoya lifted the ban on political parties in a clear demonstration that the goals of the warring parties would be achievable through peace. Sanctions against the government however, were only lifted when Buyoya - leader of the 1996 putsch - agreed to re-engage regional round of negotiations (Cunninghan, 2011).

Ironically, the following phase of the Arusha process (known as Arusha II) had a high potential to not succeed because it again failed to make fully inclusive talks, excluding again the CNDD-FDD and the Palipehutu. However, changes in the mediations allowed a different outcome regardless their exclusion. In 1999, South African president Nelson R. Mandela replaced Julius Nyerere in the task. Such substitution was welcomed by the warring parties because Mandela was viewed as a regional outsider (which, contrary to Nyerere, was expected to have no interest in the war outcome) and for holding the fame of a reconciler. Another difference between Mandela's and Nyerere's strategy is that the former held early talks to one of the parties that the later had excluded from the process (the CNDD). By doing so, Mandela managed to decrease that group's veto likelihood. Also, he imposed a deadline for the signature of the peace accord (whichever it would come to be). In fact, 13 out of the 19 parties which engaged to the talks met the deadline whilst the 6 which stayed out added their signatures less than one month later. The process proved to be successful when the new government managed to establish final cease-fires with the CNDD-FDD in 2003 and with the Palipehutu in 2008. 
This essay aimed to enrich reflection on the role of warlords in peace-building and state-building in Sub-Saharan Africa. It sought to demonstrate and assessing disputed arguments about the ethics of charging those who destroyed the states institutions with the task of rebuilding it. As it was seen, Somalia is a case that holds the argument for warlords' inclusion in both peace-building and state-building process. Such processes only began to pay off when local (warring) actors started to play a major role in the definition of the post-war Somali state. Furthermore, Burundi - and Somalia to a lesser degree - holds the argument for inclusive peace talks in despite of the unmet ethical criteria. In fact, one can argue that the two phases of the Arusha process showed that encouraging commitment to the ethical criteria through calculation is a task for the conflicts mediator. Even though the implications of empowering warlords may not be positive when it comes for precedents, public opinion, and opportunities for a cosmopolitan peace, it may be argued that running such risk may be necessary and it may be the price to be paid in exchange for reaching stability and stop killings as soon as possible.

Peace processes in both cases provide two preliminary lessons for policymakers and mediators. First, local actors (especially those involved with the war) cannot be overlooked and must be brought to the table of negotiations no matter if they are spoilers or if they are committed to cosmopolitan and liberal values. Second, although Western ethics and values may be noble, it is important not to have them as leading factors in a non-Western peace process. Both cases demonstrated that the state - as an institution and as a booty - is object of tangible bargain and it is upon the mediator the responsibility to convert this situation into one where state institutions can be solid enough for not being assaulted again. 


\section{Notas}

${ }^{1}$ Professor of International Relations at the Federal University of Pelotas (UFPel), Pelotas, Rio Grande do Sul, Brazil. e-mail: ddfcarvalho@gmail.com

${ }^{2}$ IRW in "IRW operations" stands for intervention, reconstruction and withdrawal (Ramsbotham, et al., 2011).

${ }^{3}$ Lamb, et al. (2015).

${ }^{4}$ The other cases which fit the time criteria are Angola, Côte d'Ivoire, D.R. Congo, Mozambique, Rwanda and Sudan.

${ }^{5}$ Demobilisation, Demilitarisation and Reintegration.

${ }^{6}$ Cited in Curran \& Woodhouse (2007).

${ }^{7}$ NPFL and USC stand for, respectively, National Patriotic Front of Liberia and United Somali Congress.

${ }^{8}$ United Nations Mission in Somalia. 


\section{References}

Acemoglu, D. \& Robinson, J. A., 2010. Why is Africa poor?. Economic History of Developing Regions, pp. 21-50.

African Arguments, 2011. Burundi: a Political Crisis or a Crisis in Politics?. [Online]

Available at: http://africanarguments.org/2011/08/05/burundi-a-political-crisis-or-acrisis-in-politics/ [Accessed 09 February 2016].

Al Jazeera, 2014. In Pictures: Life Returns to Mogadishu. [Online] Available at: http://www.aljazeera.com/indepth/inpictures/2014/07/pictures-mogadishu201472292331183935.html [Accessed 06 April 2016].

Anonymous, 2002. Government Recognition in Somalia and Regional Political Stability in the Horn of Africa. The Journal of Modern African Studies, 40(2), pp. 247-272.

Call, C. T., 2012. When Peace Fails: the causes and prevention of civil war recurrence. Washington: Georgetown University Press.

Clapham, C., 2013. Peacebuilding without a State: The Somali Experience. In: D. Curtis \& G. A. Dzinesa, eds. Peacebuilding, Power, and Politics in Africa. Johannesburg: Wits University Press, pp. 295-310.

Cunninghan, D. E., 2011. Barriers to Peace in Civil War. New York: Cambridge University Press.

Curran, D. \& Woodhouse, T., 2007. Cosmopolitan peacekeeping and peacebuilding in Sierra Leone: what can Africa Contribute. International Affairs, 86(6), pp. 1055-70.

Curtis, D., 2013. The Contested Politics of Peacebuilding in Africa. In: D. Curtis \& G. A. Dzinesa, eds. Peacebuilding, Power, and Politics in Africa. Johannesburg: Wits University Press, pp. 01-28.

Doyle, M. W., 1999. A Liberal View: Preserving and Expanding the Liberal Pacific Union. In: T. V. Paul \& J. A. Hall, eds. International Order and the Future of World Politics. Oxford: Oxford University Press, pp. 41-66.

Duffield, M., 2001. Global Governance and the New Wars. London: Zed Books. Duyvesteyn, I., 2005. Clausweitz and African War: politics and strategy in Liberia and Somalia. Abingdon: Taylor \& Francis.

Englebert, P., 2000b. State Legitimacy and Development in Africa. Boulder: Lyenne Ryenner.

Evans, G. J., 2008. The responsibility to protect: ending mass atrocity crimes once and for all. Washington: Brookings Institution Press.

Fukuyama, F., 2005. Construção de estados: governo e organização mundial no século XXI. Rio de Janeiro: Rocco. 
Fukuyama, F., 2011. As Origens da Ordem Política: dos tempos pré-humanos até a Revolução Francesa. Rio de Janeiro: Rocco.

High-Level Panel on Threats, Challenges and Changes, 2004. A More Secure World: our shared responsibility, New York: United Nations.

Lamb, R. D., Mixon, K. \& Minot, S., 2015. The Uncertain Transition from Stability to Peace, Nova Iorque: Center for Strategic \& International Studies.

Lidén, K., 2009. Building Peace between Global and Local Politics: the Cosmopolitical Ethics of Liberal Peacebuilding. International Peacekeeping, 16(5), pp. 616-34.

Mansfield, E. D. \& Snyder, J., 2005. Electing to Fight: why emerging democracies go to war. Cambridge: Belfer Center for Science and International Affairs.

McDougall, D., 2014. Responsibility While Protecting - Brazil's proposal for modifying Responsibility to Protect. Global Responsibility to Protect, Volume 6, pp. 64-87.

Menkhaus, K., 1996. International Peacebuilding and the Dynamics of Local and National Reconciliation in Somalia. International Peacekeeping, 3(1), pp. 42-67.

Menkhaus, K., 2006. Governance without Government in Somalia - spoilers, state building, and the politics of coping. International Security, 31(3), pp. 74-106.

Miller, P. D., 2013. Armed State Building: confronting state failure, 1899-2012. New York: Cornell University Press.

Mills, G., 2014. Why States Recover: changing walking societies into winning nations, from Afghanistan to Zimbabwe. London: C. Hurst \& Co..

Molloy, D., 2004. The gender perspective as a deterrent to spoilers: the Sierra Leone experience. Conflict Trends, Volume 2, pp. 16-19.

Paris, R., 2004. At War's End: Building Peace after Civil Conflict. Cambridge: Cambridge University Press.

Paris, R. \& Sisk, T. D., 2009. Understanding the contradictions of postwar statebuilding. In: R. Paris \& T. D. Sisk, eds. The Dilemmas of Statebuilding - confronting the contradictions of postwar peace operations. New York: Routledge, pp. 01-20.

Patman, R. G., 2007. Globalization, the demise of the Cold War, and the disintegration of the Somali State. s.l., International Studies Association Annual Conference.

Ramsbotham, O., Woodhouse, T. \& Miall, H., 2011. Contemporary Conflict Resolution - the prevention, management and transformation of deadly conflicts. Cambridge: Polity Press.

Riedl, R. B., 2014. Authoritarian Origins of Demcoratic Party Systems in Africa. Nova Iorque: Cambridge University Press. 
Sisk, T. D., 2009. Burundi: empowering the fragile center. In: International Mediation in Civil Wars: bargaining with bullets. New York: Routledge, pp. 133-46.

Southall, R., 2006. A Long Prelude to Peace: African Involvement in Ending Burundi's War. In: Ending Africa's Wars: progressing to peace. Hampshire: Ashgate Publishing Limited, pp. 201-21.

United Nations, 1992. An agenda for peace: preventive diplomacy, peacemaking and peace-keeping, Nova Iorque: s.n.

United Nations, 2005. Security Council Resolution 1645. s.1., s.n.

United Nations, 2014. List of Peacekeeping Operations 1948-2013. [Online] Available at: http://www.un.org/en/peacekeeping/documents/operationslist.pdf [Accessed 07 April 2016].

Woodward, P., 2003. The Horn of Africa: politics and international relations. New York: I.B. Tauris.

Worldwide Governance Indicators, 2014. The Worldwide Governance Indicators (WGI) Project. [Online] Available at: http://info.worldbank.org/governance/wgi/index.aspx\#home [Accessed 09 February 2015]. 